\title{
Percutaneous balloon dilatation of the mitral valve in patients who were unsuitable for surgical treatment
}

\author{
T R D Shaw, D McAreavey, A R Essop, A D Flapan, A T Elder
}

\begin{abstract}
Objective-To assess the effects on haemodynamic function and symptoms of percutaneous balloon dilatation of mitral stenosis in patients unable to undergo surgical treatment because of associated medical/cardiac problems.

Design-A review of clinical outcome in 28 patients (of 108 undergoing balloon dilatation of the mitral valve) who were unsuitable for surgery.
\end{abstract}

Setting-A tertiary cardiac referral centre: some patients referred were from other cardiac centres in Scotland.

Patients-28 patients judged by cardiac surgeons to be unsuitable for valve replacement or valvotomy because of respiratory disease (15 patients), nonmitral cardiac disease (6), multi-organ impairment (5), psychiatric problems (1) or dense intrathoracic adhesions (1).

Interventions-Percutaneous anterograde balloon dilatation of the mitral valve with polyethylene/polyvinyl balloons in 20 patients and the Inoue balloon in eight patients.

Main outcome measures-Haemodynamic variables were measured before and immediately after mitral valve dilatation. Patient survival and symptom class (New York Heart Association) were followed for a year after the procedure.

Results-Dilatation at the mitral orifice was achieved in all cases. The mean (SD) pressure drop across the valve fell from $13.9(5.3)$ to $5.6(2.5) \mathrm{mm}$ $\mathrm{Hg}$, cardiac output rose from $3 \cdot 18(1 \cdot 02)$ to $3.96(2.5) 1 / \mathrm{min}$, and valve area increased from $0.78(0.32)$ to $1.58(0.56)$ $\mathrm{cm}^{2}$. The procedure was well tolerated by most patients, even those with metabolic/electrolyte disturbance, severe obstructive airways disease, myocardial impairment, and coronary disease. In three patients a small shunt developed at the atrial level: none developed severe mitral reflux. The two patients who required assisted ventilation died soon after the procedure and in one patient with severe coronary artery disease myocardial infarction developed and she died in cardiogenic shock. Early symptomatic improvement was reported by 23 of the 25 survivors, though the increase in exercise capacity was often limited by their non-mitral disease. At one year follow up a further 6 patients had died because of their additional disease: 15 continued to show symptomatic improvement.

Conclusions-Percutaneous balloon dilatation of the mitral valve is a useful new option in patients who are too ill to undergo cardiac surgery; but longer term benefit can be limited by the associated disease.

The introduction of percutaneous balloon dilatation created a new option in the treatment of mitral stenosis. ${ }^{12}$ The place of mitral balloon dilatation in relation to surgical treatment has still to be fully established but balloon dilatation may be useful in patients with additional medical problems that put them at an unacceptably high risk for operation. In Western Europe and North America the proportion of elderly patients with severe mitral stenosis and additional disease is increasing as acute rheumatic fever becomes less common. ${ }^{3}$ Also in some patients restenosis develops after a successful surgical valvotomy carried out many years earlier. We report the results of percutaneous balloon dilatation of the mitral valve in patients in whom surgical treatment was regarded as unacceptable.

\section{Patients and methods}

PATIENTS

Each patient had been judged by a cardiac surgeon as unacceptable for operation because of medical problems other than mitral valve disease. Patients whom a surgeon was reluctant to accept because of age and or general frailty were not included in this series because these criteria are less clear cut. Nor were the patients who had one or more moderately severe medical problems that would have added to the risk of surgery but did not constitute an absolute contraindication to operation.

There were four groups of principal contraindication to operation:

Group $A$-Severe chronic obstructive airways disease. There were 15 patients in this group (table 1). They often also had additional problems such as obesity, diabetes, peripheral 
Table 1 Clinical characteristics and haemodynamic data before and after balloon dilatation of the mitral valve in 28 patients unsuitable for mitral valve replacement

\begin{tabular}{|c|c|c|c|c|c|c|c|c|c|c|c|c|c|c|c|c|c|c|c|}
\hline \multirow{2}{*}{$\begin{array}{l}\text { Patient } \\
\text { no }\end{array}$} & \multirow[b]{2}{*}{ Sex } & \multirow[b]{2}{*}{ Age } & \multirow[b]{2}{*}{ Rhythm } & \multirow[b]{2}{*}{$V T Y$} & \multirow{2}{*}{$\begin{array}{l}\text { NYHA } \\
\text { Class } \\
\text { (before) }\end{array}$} & \multirow{2}{*}{$\begin{array}{l}\text { Calci- } \\
\text { fication } \\
\text { grade }\end{array}$} & \multicolumn{2}{|c|}{$\begin{array}{l}R V \text { systolic } \\
\text { pressure } \\
(\mathrm{mm} / \mathrm{Hg})\end{array}$} & \multicolumn{2}{|c|}{$\begin{array}{l}\text { Mean } L A \\
\text { pressure } \\
(\mathrm{mm} / \mathrm{Hg})\end{array}$} & \multicolumn{2}{|c|}{$\begin{array}{l}\text { Mitral } \\
\text { gradient } \\
(\mathbf{m m} / \mathbf{H g})\end{array}$} & \multicolumn{2}{|c|}{$\begin{array}{l}\text { Cardiac } \\
\text { output } \\
\text { (l/min })\end{array}$} & \multicolumn{2}{|l|}{$\begin{array}{l}\text { Valve } \\
\text { area } \\
\left(\mathrm{cm}^{2}\right)\end{array}$} & \multirow{2}{*}{$\begin{array}{l}\text { Left to } \\
\text { right } \\
\text { shunt }\end{array}$} & \multirow{2}{*}{$\begin{array}{l}\text { NYHA } \\
\text { class } \\
(4-8 w k)\end{array}$} & \multirow{2}{*}{$\begin{array}{l}\text { NYHA } \\
\text { class } \\
\text { l year }\end{array}$} \\
\hline & & & & & & & $B$ & $A$ & $B$ & $A$ & $B$ & $A$ & $B$ & $A$ & $B$ & $A$ & & & \\
\hline \multicolumn{20}{|c|}{ Group A: } \\
\hline $\begin{array}{c}1 \\
2 \\
3 \\
4 \\
5 \\
6 \\
7 \\
8 \\
9 \\
10 \\
11 \\
12 \\
13 \\
14 \\
15 \\
\text { Mean (S }\end{array}$ & $\begin{array}{l}\mathbf{F} \\
\mathbf{M} \\
\mathbf{F} \\
\mathbf{F} \\
\mathbf{F} \\
\mathbf{F} \\
\mathbf{F} \\
\mathbf{M} \\
\mathbf{M} \\
\mathbf{F} \\
\mathbf{F} \\
\mathbf{F} \\
\mathbf{M} \\
\mathbf{F} \\
\mathbf{F} \\
\mathbf{D})\end{array}$ & $\begin{array}{ll}69 & \mathrm{~A} \\
77 & \mathrm{~A} \\
70 & \mathrm{~A} \\
56 & \mathrm{~A} \\
55 & \mathrm{~A} \\
71 & \mathrm{~A} \\
65 & \mathrm{~A} \\
63 & \mathrm{~A} \\
55 & \mathrm{~S} \\
75 & \mathrm{~A} \\
53 & \mathrm{~A} \\
69 & \mathrm{~A} \\
71 & \mathrm{~A} \\
65 & \mathrm{~A} \\
71 & \mathrm{~A} \\
\mathbf{6 5} \cdot 6 & (7 \cdot 7)\end{array}$ & $\begin{array}{l}\text { AF } \\
\text { AF } \\
\text { AF } \\
\text { AF } \\
\text { AF } \\
\text { AF } \\
\text { AF } \\
\text { AF } \\
\text { SR } \\
\text { AF } \\
\text { AF } \\
\text { AF } \\
\text { AF } \\
\text { AF } \\
\text { AF }\end{array}$ & $\begin{array}{l}0 \\
0 \\
0 \\
0 \\
0 \\
0 \\
+ \\
+ \\
0 \\
+ \\
0 \\
0 \\
0 \\
0 \\
+\end{array}$ & $\begin{array}{l}\text { IV } \\
\text { IV } \\
\text { IV } \\
\text { III } \\
\text { III } \\
\text { IV } \\
\text { IV } \\
\text { IV } \\
\text { III } \\
\text { III } \\
\text { IV } \\
\text { IV } \\
\text { IV } \\
\text { IV } \\
\text { III }\end{array}$ & $\begin{array}{l}3 \\
3 \\
3 \\
0 \\
1 \\
2 \\
2 \\
3 \\
0 \\
3 \\
3 \\
2 \\
0 \\
3 \\
0\end{array}$ & $\begin{array}{c}45 \\
42 \\
57 \\
55 \\
45 \\
90 \\
58 \\
82 \\
78 \\
70 \\
105 \\
52 \\
37 \\
83 \\
42 \\
70 \cdot 7 \\
(22 \cdot 2)\end{array}$ & $\begin{array}{l}\text { NR } \\
\text { NR } \\
\text { NR } \\
\text { NR } \\
\text { NR } \\
75 \\
35 \\
54 \\
52 \\
49 \\
90 \\
45 \\
35 \\
60 \\
45 \\
54 \cdot 0 \\
(17 \cdot 2)\end{array}$ & $\begin{array}{l}35 \\
19 \\
16 \\
22 \\
23 \\
24 \\
25 \\
24 \\
32 \\
27 \\
33 \\
29 \\
18 \\
28 \\
21 \\
25 \cdot 0 \\
(5 \cdot 6)\end{array}$ & $\begin{array}{r}7 \\
11 \\
25 \\
9 \\
17 \\
10 \\
6 \\
17 \\
19 \\
24 \\
22 \\
29 \\
16 \\
27 \\
18 \\
17 \cdot 1 \\
(7 \cdot 3)\end{array}$ & $\begin{array}{c}22 \\
10 \\
8 \\
15 \\
7 \\
23 \\
13 \\
18 \\
25 \\
16 \\
23 \\
10 \\
12 \\
14 \\
6 \\
14 \cdot 8 \\
(6 \cdot 2)\end{array}$ & $\begin{array}{r}7 \\
2 \\
12 \\
1 \\
5 \\
4 \\
1 \\
7 \\
8 \\
5 \\
4 \\
9 \\
6 \\
5 \\
4 \\
5 \cdot 3 \\
(2 \cdot 9)\end{array}$ & $\begin{array}{l}2 \cdot 4 \\
2 \cdot 8 \\
2.8 \\
2 \cdot 3 \\
3 \cdot 8 \\
2 \cdot 2 \\
2 \cdot 3 \\
3 \cdot 4 \\
4 \cdot 4 \\
2.8 \\
1.9 \\
4 \cdot 1 \\
5 \cdot 0 \\
3 \cdot 4 \\
3.0 \\
3 \cdot 10 \\
(0.89)\end{array}$ & $\begin{array}{l}2 \cdot 9 \\
4 \cdot 2 \\
3 \cdot 7 \\
2 \cdot 3 \\
4 \cdot 6 \\
3 \cdot 1 \\
2 \cdot 7 \\
3 \cdot 9 \\
4 \cdot 5 \\
3 \cdot 1 \\
2 \cdot 5 \\
4 \cdot 1 \\
8 \cdot 5 \\
3 \cdot 7 \\
3 \cdot 4 \\
3 \cdot 81 \\
(1 \cdot 47)\end{array}$ & $\begin{array}{l}0.46 \\
0.69 \\
0.65 \\
0.46 \\
1.18 \\
0.34 \\
0.56 \\
0.75 \\
0.80 \\
0.58 \\
0.30 \\
1.14 \\
1.46 \\
0.68 \\
0.90 \\
0.73 \\
(0.32)\end{array}$ & $\begin{array}{l}0.91 \\
2.23 \\
0.76 \\
1.89 \\
1.64 \\
1.17 \\
2.30 \\
1.25 \\
1.40 \\
1.01 \\
1.03 \\
1.16 \\
3.50 \\
1.28 \\
1.44 \\
1.53 \\
(0.71)\end{array}$ & $\begin{array}{l}0 \\
0 \\
0 \\
0 \\
0 \\
0 \\
1 \cdot 2 \\
0 \\
0 \\
1 \cdot 2 \\
0 \\
0 \\
0 \\
0 \\
0\end{array}$ & $\begin{array}{l}\text { Died } \\
\text { III } \\
\text { II } \\
\text { II } \\
\text { II } \\
\text { II } \\
\text { III } \\
\text { II } \\
\text { II } \\
\text { III } \\
\text { I } \\
\text { IV } \\
\text { II } \\
\text { Died } \\
\text { II }\end{array}$ & $\begin{array}{l}\text { Died } \\
\text { Died } \\
\text { III } \\
\text { II } \\
\text { II } \\
\text { II } \\
\text { III } \\
\text { Died } \\
\text { II } \\
\text { III } \\
\text { I } \\
\text { IV } \\
\text { II } \\
\text { Died } \\
\text { II }\end{array}$ \\
\hline \multicolumn{20}{|c|}{ Group B: } \\
\hline $\begin{array}{l}16 \\
17 \\
18 \\
19 \\
20 \\
21\end{array}$ & $\begin{array}{l}M \\
M \\
\mathbf{M} \\
\mathrm{F} \\
\mathbf{F} \\
\mathbf{F}\end{array}$ & $\begin{array}{ll}59 & \mathrm{~A} \\
74 & \mathrm{~A} \\
78 & \mathrm{~A} \\
75 & \mathrm{~S} \\
\mathbf{7 4} & \mathrm{A} \\
\mathbf{7 4} & \mathrm{A}\end{array}$ & $\begin{array}{l}\mathrm{AF} \\
\mathrm{AF} \\
\mathrm{AF} \\
\mathrm{SR} \\
\mathrm{AF} \\
\mathrm{AF}\end{array}$ & $\begin{array}{l}0 \\
+ \\
0 \\
0 \\
0 \\
0\end{array}$ & $\begin{array}{l}\text { IV } \\
\text { III } \\
\text { IV } \\
\text { IV } \\
\text { III } \\
\text { IV }\end{array}$ & $\begin{array}{l}0 \\
0 \\
3 \\
3 \\
2 \\
0\end{array}$ & $\begin{array}{r}52 \\
53 \\
27 \\
153 \\
40 \\
45\end{array}$ & $\begin{array}{r}\text { NR } \\
\text { NR } \\
32 \\
130 \\
37 \\
48\end{array}$ & $\begin{array}{l}28 \\
19 \\
19 \\
36 \\
22 \\
23\end{array}$ & $\begin{array}{l}29 \\
16 \\
12 \\
29 \\
17 \\
29\end{array}$ & $\begin{array}{r}13 \\
11 \\
3 \\
20 \\
11 \\
13\end{array}$ & $\begin{array}{l}6 \\
6 \\
1 \\
7 \\
6 \\
5\end{array}$ & $\begin{array}{l}3.1 \\
2.7 \\
2.8 \\
3.1 \\
3.4 \\
3.5\end{array}$ & $\begin{array}{l}3.1 \\
4.0 \\
3.7 \\
4.6 \\
5.0 \\
4.0\end{array}$ & $\begin{array}{l}0.78 \\
0.77 \\
1.18 \\
0.60 \\
0.84 \\
0.85\end{array}$ & $\begin{array}{l}1.41 \\
1.43 \\
2.02 \\
1.63 \\
1.79 \\
1.57\end{array}$ & $\begin{array}{l}0 \\
0 \\
0 \\
0 \\
1 \cdot 3 \\
0\end{array}$ & $\begin{array}{l}\text { II } \\
\text { II } \\
\text { II } \\
\text { III } \\
\text { III }\end{array}$ & $\begin{array}{l}\text { Died } \\
\text { II } \\
\text { II } \\
\text { IV } \\
\text { II } \\
\text { Died }\end{array}$ \\
\hline Mean (S & & $72 \cdot 3(6 \cdot 7)$ & & & & & $\begin{array}{c}66 \cdot 2 \\
(58 \cdot 3)^{\star}\end{array}$ & $\begin{array}{r}61.7 \\
\quad(45.9)\end{array}$ & $\begin{array}{l}24.5 \\
(6.5)\end{array}$ & $\begin{array}{l}22.2 \\
(7 \cdot 8)\end{array}$ & $\begin{array}{l}11.8 \\
(5 \cdot 4)\end{array}$ & $\begin{array}{r}5 \cdot 2 \\
(2 \cdot 1)\end{array}$ & $\begin{array}{l}3 \cdot 10 \\
(0 \cdot 32)\end{array}$ & $\begin{array}{l}4.06 \\
(0 \cdot 67)\end{array}$ & $\left\{\begin{array}{l}0.83 \\
(1 \cdot 19)\end{array}\right.$ & $\begin{array}{l}1.64 \\
(0.23)\end{array}$ & & & \\
\hline \multicolumn{20}{|c|}{ Group C: } \\
\hline $\begin{array}{l}22 \\
23 \\
24 \\
25 \\
26\end{array}$ & $\begin{array}{l}\mathbf{F} \\
\mathbf{M} \\
\mathbf{F} \\
\mathbf{F} \\
\mathbf{F}\end{array}$ & $\begin{array}{ll}63 & \text { A } \\
69 & \text { A } \\
58 & \text { A } \\
72 & \text { A } \\
60 & \text { A }\end{array}$ & $\begin{array}{l}\mathrm{AF} \\
\mathrm{AF} \\
\mathrm{AF} \\
\mathrm{AF} \\
\mathrm{AF}\end{array}$ & $\begin{array}{l}0 \\
0 \\
+ \\
0 \\
0\end{array}$ & $\begin{array}{l}\text { IV } \\
\text { IV } \\
\text { IV } \\
\text { IV } \\
\text { III }\end{array}$ & $\begin{array}{l}3 \\
0 \\
3 \\
0 \\
0\end{array}$ & $\begin{array}{l}75 \\
88 \\
60 \\
65 \\
50\end{array}$ & $\begin{array}{r}\text { NR } \\
75 \\
60 \\
60 \\
50\end{array}$ & $\begin{array}{l}22 \\
41 \\
23 \\
20 \\
29\end{array}$ & $\begin{array}{l}15 \\
23 \\
23 \\
22 \\
27\end{array}$ & $\begin{array}{l}14 \\
16 \\
12 \\
14 \\
11\end{array}$ & $\begin{array}{l}7 \\
5 \\
6 \\
7 \\
6\end{array}$ & $\begin{array}{l}2.3 \\
2.2 \\
1.9 \\
4.9 \\
5.8\end{array}$ & $\begin{array}{l}3.6 \\
3.5 \\
1.9 \\
6.0 \\
5.7\end{array}$ & $\begin{array}{l}0.60 \\
0.56 \\
0.58 \\
1.11 \\
1.62\end{array}$ & $\begin{array}{l}1.28 \\
1.72 \\
0.93 \\
1.99 \\
2.29\end{array}$ & $\begin{array}{l}0 \\
0 \\
0 \\
0 \\
0\end{array}$ & $\begin{array}{l}\text { III } \\
\text { Died } \\
\text { III } \\
\text { III } \\
\text { II }\end{array}$ & $\begin{array}{l}\text { Died } \\
\text { Died } \\
\text { IV } \\
\text { Died } \\
\text { II }\end{array}$ \\
\hline Mean (S & & $64 \cdot 4(5 \cdot 9)$ & & & & & $\begin{array}{l}65.7 \\
(16.0)^{*}\end{array}$ & $\begin{array}{l}61 \cdot 2 \\
(10 \cdot 3)\end{array}$ & $\begin{array}{l}27 \cdot 3 \\
(8 \cdot 5)\end{array}$ & $\begin{array}{l}22 \cdot 1 \\
(4 \cdot 3)\end{array}$ & $\begin{array}{l}13 \cdot 4 \\
(4 \cdot 3)\end{array}$ & $\begin{array}{l}6 \cdot 2 \\
(0 \cdot 8)\end{array}$ & $\begin{array}{l}3.42 \\
(1.79)\end{array}$ & $\begin{array}{l}4 \cdot 14 \\
(1 \cdot 70)\end{array}$ & $\begin{array}{l}0.89 \\
(0.46)\end{array}$ & $\begin{array}{l}1.64 \\
(0.54)\end{array}$ & & & \\
\hline \multicolumn{20}{|c|}{ Group D: } \\
\hline $\begin{array}{l}27 \\
28\end{array}$ & $\begin{array}{l}\mathbf{F} \\
\mathbf{F}\end{array}$ & $\begin{array}{ll}59 & \mathrm{~A} \\
70 & \mathrm{~A}\end{array}$ & $\begin{array}{l}\mathbf{A F} \\
\mathbf{A F}\end{array}$ & $\begin{array}{l}0 \\
+\end{array}$ & $\begin{array}{l}\text { III } \\
\text { IV }\end{array}$ & $\begin{array}{l}3 \\
2\end{array}$ & $\begin{array}{l}70 \\
65\end{array}$ & $\begin{array}{l}60 \\
50\end{array}$ & $\begin{array}{l}29 \\
25\end{array}$ & $\begin{array}{l}17 \\
20\end{array}$ & $\begin{array}{l}14 \\
17\end{array}$ & $\begin{array}{l}8 \\
9\end{array}$ & $\begin{array}{l}2.2 \\
4.7\end{array}$ & $\begin{array}{l}3.2 \\
5.6\end{array}$ & $\begin{array}{l}0.55 \\
1.07\end{array}$ & $\begin{array}{l}1.65 \\
1.67\end{array}$ & $\begin{array}{l}0 \\
0\end{array}$ & I & I \\
\hline \multicolumn{2}{|c|}{ Mean (SD) } & $64 \cdot 5(7 \cdot 7)$ & & & & & $\begin{array}{l}67.5 \\
(3.5)\end{array}$ & $\begin{array}{l}55 \cdot 2 \\
(7 \cdot 1)\end{array}$ & $\begin{array}{l}27 \cdot 4 \\
(2 \cdot 8)\end{array}$ & $\begin{array}{l}18 \cdot 5 \\
(2 \cdot 1)\end{array}$ & $\begin{array}{l}15 \cdot 5 \\
(2 \cdot 1)\end{array}$ & $\begin{array}{l}8.5 \\
(0.7)\end{array}$ & $\begin{array}{l}3.45 \\
(1.77)\end{array}$ & $\begin{array}{l}4.40 \\
(1.69)\end{array}$ & $\begin{array}{l}0.81 \\
(0.36)\end{array}$ & $\begin{array}{l}1.66 \\
(0.01)\end{array}$ & & & \\
\hline
\end{tabular}

SR, sinus rhythm; AF, atrial fibrillation; B, before dilatation; A, after dilatation; LA, left atrial; VTY, previous valvotomy; RV, right ventricular; NR, not recorded. $\star$ Four patients.

and cerebral vascular disease, left ventricular impairment, and coronary artery disease.

Group B-Severe non-mitral cardiac disease: six patients were in this category. Three had severe left ventricular impairment (ejection fractions 10,15 , and $25 \%$ and the last two had additional coronary disease) and three had severe diffuse coronary artery disease unsuitable for coronary artery bypass grafts.

Group C-Multiorgan impairment: five patients had severe multi-system medical problems (table 2).

Group D-Miscellaneous: one (patient 27) had severe depression and schizophrenia and one (patient 28), who had previously undergone mitral valvotomy, had dense intrathoracic adhesions that caused an attempt at valve replacement to be abandoned.

The mean (SD) age of the 28 patients was $66.7(7.4)$ years (range 53-78). There were 21 women and seven men. A history of rheumatic fever was reported by eight $(29 \%)$ and seven $(25 \%)$ had had a valvotomy, including two patients had two previous surgical valvotomies. The mean daily dose of frusemide at the time of dilatation was $144 \mathrm{mg}$ (range $40-$ $500 \mathrm{mg}$ ). These 28 patients had been referred from cardiac departments throughout

Table 2 Patients with multi-organ impairment in addition to mitral stenosis

\begin{tabular}{|c|c|c|c|c|c|c|}
\hline \multirow[b]{2}{*}{ Patient no } & \multirow[b]{2}{*}{ Patient diagnosis } & \multicolumn{5}{|c|}{ Organ impairment } \\
\hline & & Renal & Hepatic & Cerebral & Vascular & Haematological \\
\hline $\begin{array}{l}22 \\
23\end{array}$ & $\begin{array}{l}\text { Diabetes mellitus, atherosclerosis/gangrene, low output state } \\
\text { Systemic lupus erythematosus, vasculitis, } \\
\text { obstructive airways disease, cerebrovascular disease, left ventricular } \\
\text { impairment }\end{array}$ & $\stackrel{+}{+}$ & $\stackrel{+}{+}$ & $\begin{array}{l}+ \\
+\end{array}$ & $\stackrel{+}{+}$ & $\stackrel{+}{+}$ \\
\hline 24 & $\begin{array}{l}\text { Poor left ventricular function, recurrent ventricular tachycardia, } \\
\text { persistent electrolyte imbalance, low output state }\end{array}$ & + & + & + & - & - \\
\hline 25 & $\begin{array}{l}\text { Dense hemiplegia, low output state, } \\
\text { severe tricuspid reflux }\end{array}$ & + & + & + & - & - \\
\hline 26 & $\begin{array}{l}\text { Glomerulonephritis, rheumatoid arthritis, anaemia, } \\
\text { hypertension, left ventricular impairment }\end{array}$ & + & - & - & + & + \\
\hline
\end{tabular}




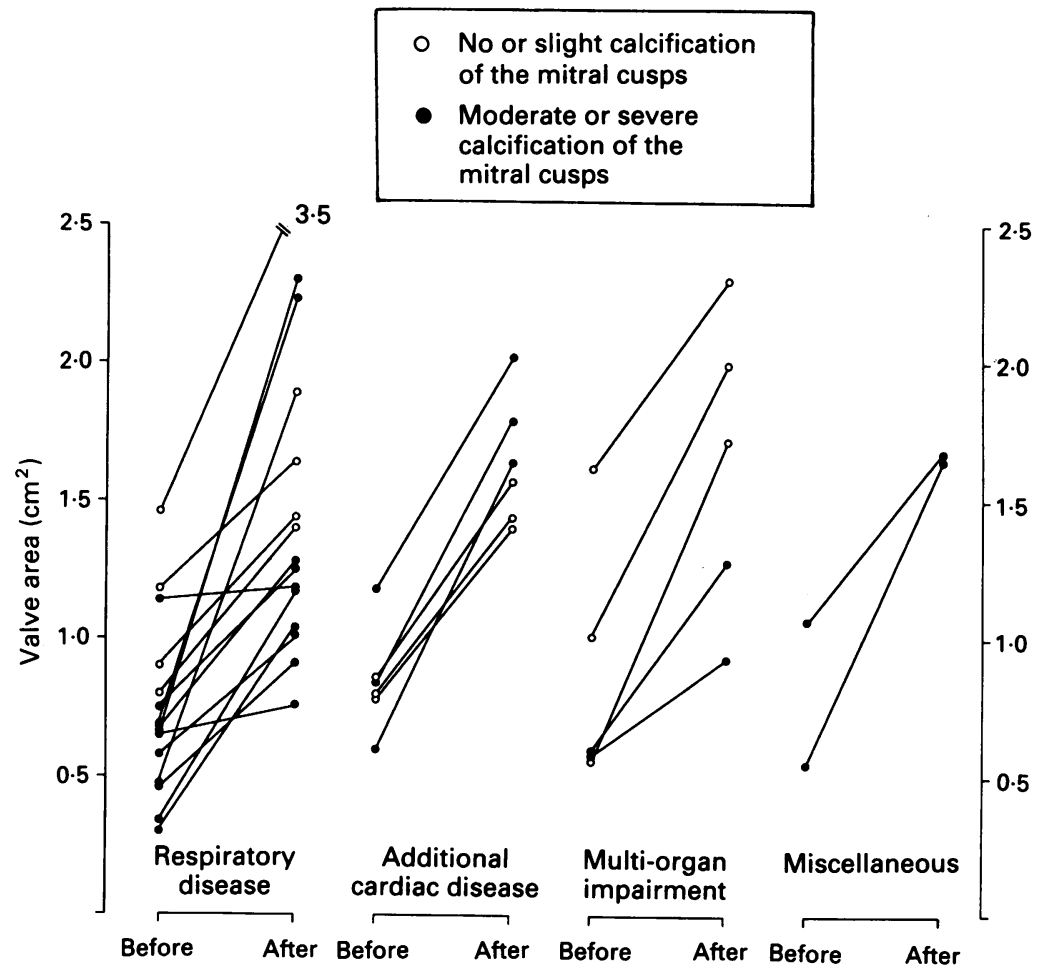

Figure 1 Valve area before and immediately after mitral balloon dilatation: the patients are grouped according to the principal type of contraindication to surgery (see text).

Scotland and they constituted $26 \%$ of the patients undergoing balloon dilatation of the mitral valve. Seven of the 28 patients could not leave hospital because of severe symptoms and had urgently required balloon dilatation.

\section{DILATATION TECHNIQUE}

The dilatation procedures were carried out in the cardiac laboratory with oxygen and standard resuscitation equipment available. After the procedure the patients were monitored in the coronary care unit.

Patients with respiratory disease were given no premedication but the others were given diazepam (10 mg orally) and, if required, intravenous morphine. One patient (case 1) with severe orthopnoea required a general anaesthetic. Balloon catheters were inserted at the groin under local anaesthesia. The Brockenbrough catheter/needle and the dilatation balloons were advanced to the left atrium from the right femoral vein. An F6 pigtail catheter via the right or left femoral artery was used to monitor aortic pressure and to measure the valve gradient and mitral reflux. An F8 introducer sheath was placed in the left femoral vein to allow access for a pacing electrode and fluid/drug administration if

Table 3 Changes in indices of renal and hepatic function and in cerebral function before and after balloon dilatation of the mitral valve in the five patients with multiorgan impairment

\begin{tabular}{|c|c|c|c|c|c|}
\hline \multirow[b]{2}{*}{ Patient } & \multicolumn{2}{|c|}{ Blood urea (mmol/l) } & \multicolumn{2}{|c|}{ Bilirubin ( $\mu \mathrm{mol} / \mathrm{l})$} & \multirow[b]{2}{*}{ Cerebral function } \\
\hline & Before & After & Before & After & \\
\hline $\begin{array}{l}22 \\
23 \\
24 \\
25 \\
26\end{array}$ & $\begin{array}{l}17 \cdot 1 \\
24 \cdot 3 \\
21 \cdot 7 \\
34 \cdot 7 \\
35 \cdot 5\end{array}$ & $\begin{array}{r}6 \cdot 4 \\
15 \cdot 4 \\
6 \cdot 6 \\
16 \cdot 3 \\
35 \cdot 4\end{array}$ & $\begin{array}{l}49 \\
64 \\
58 \\
41 \\
-\end{array}$ & $\begin{array}{l}42 \\
74 \\
35 \\
34 \\
\end{array}$ & $\begin{array}{l}\text { Improved } \\
\text { Worsened (CVA) } \\
\text { Improved } \\
\text { Improved }\end{array}$ \\
\hline
\end{tabular}

needed. Patients were treated with warfarin for at least four weeks unless anticoagulation was contraindicated and at the time of the procedure all patients were given heparin (100 units/kg body weight).

In 20 patients mitral dilatation was carried out with polyethylene (Mansfield Scientific) or polyvinyl/Trefoil (Schneider-Shiley) balloons by the technique described by Lock et $a l^{2}$ except that the guide wire was usually advanced to the left ventricle rather than to the aorta. The Trefoil model $(3 \times 12 \mathrm{~mm})$ was used for two patients. In the 18 patients treated by polyethylene balloon a single $25 \mathrm{~mm}$ balloon was used in 11 and a double balloon technique ${ }^{4}$ was used in seven, with sizes from $15+15 \mathrm{~mm}$ to $15+25 \mathrm{~mm}$. The Inoue rubber-nylon balloon technique ${ }^{5}$ was used for eight patients, with final dilation sizes of $27 \mathrm{~mm}$ (one patient), $28 \mathrm{~mm}$ (two patients), $30 \mathrm{~mm}$ (three patients), and $32 \mathrm{~mm}$ (two patients). All procedures were carried out by one primary operator (TRDS).

Pressures were recorded with zero at $10 \mathrm{~cm}$ above the table. Cardiac output was calculated by the Fick principle from oxygen saturations and with an assumed oxygen consumption. After dilatation right heart saturations were measured in the venae cavae to avoid arterial blood from the atrial septal puncture site. The left to right shunt was estimated from right heart oxygen saturations. The mitral valve area was calculated from the modified Gorlin equation: ${ }^{6}$ diastolic flow/ $38 \times \sqrt{\text { mean gradient. Mitral reflux was }}$ assessed by the method of Sellars et al. ${ }^{8}$

\section{Results}

In all patients dilatation at the mitral valve was achieved. Table 1 gives the haemodynamic findings before dilatation and after the final dilatation for each group of patients. Valve area increased in all patients but to a degree that varied from minimal to substantial. For the 28 patients overall, mean (SD) valve area increased from $0.78(0.32)$ to $1.58(0.56)$ $(+103 \%)$. In those who had mild or no mitral valve calcification valve area increased from $0.95(0.35)$ to $1.84(0.61) \mathrm{cm}^{2}$, and in those with moderate or heavy calcification it increased from $0.68(0.25)$ to $1.41(0.47) \mathrm{cm}^{2}$ (fig 1). For the 28 patients overall, the valve gradient was reduced from $13.9(5.3)$ to $5.6(2.5) \mathrm{mm} \mathrm{Hg}$ $(-60 \%)$, cardiac output rose from $3.18(1.02)$ to $3.96(1.33) 1 / \mathrm{min}(+25 \%)$, and mean left atrial pressure fell from $25.4(6.0)$ to $19 \cdot 1(6.9)$ $\mathrm{mm} \mathrm{Hg}(-25 \%)$. Right ventricular systolic pressure, measured before and after the procedure in 20 patients fell from $68.5(28.5)$ to $57 \cdot 1(22 \cdot 5) \mathrm{mm} \mathrm{Hg}(-17 \%)$. All the changes were statistically significant $(p<0.001$, paired $t$ test).

Three of the five patients with multi-organ problems who had renal or hepatic impairment showed metabolic improvement within a few days after the procedure (table 3 ).

The mean duration of the total catheterisation procedure, which included diagnostic catheterisation measurements and coronary 
Figure 2 Symptoms before, at 1-2 months after and at one year after balloon dilatation of the mitral valve in patients in groups $A-D$. NYHA, New York Heart

Association symptom class.

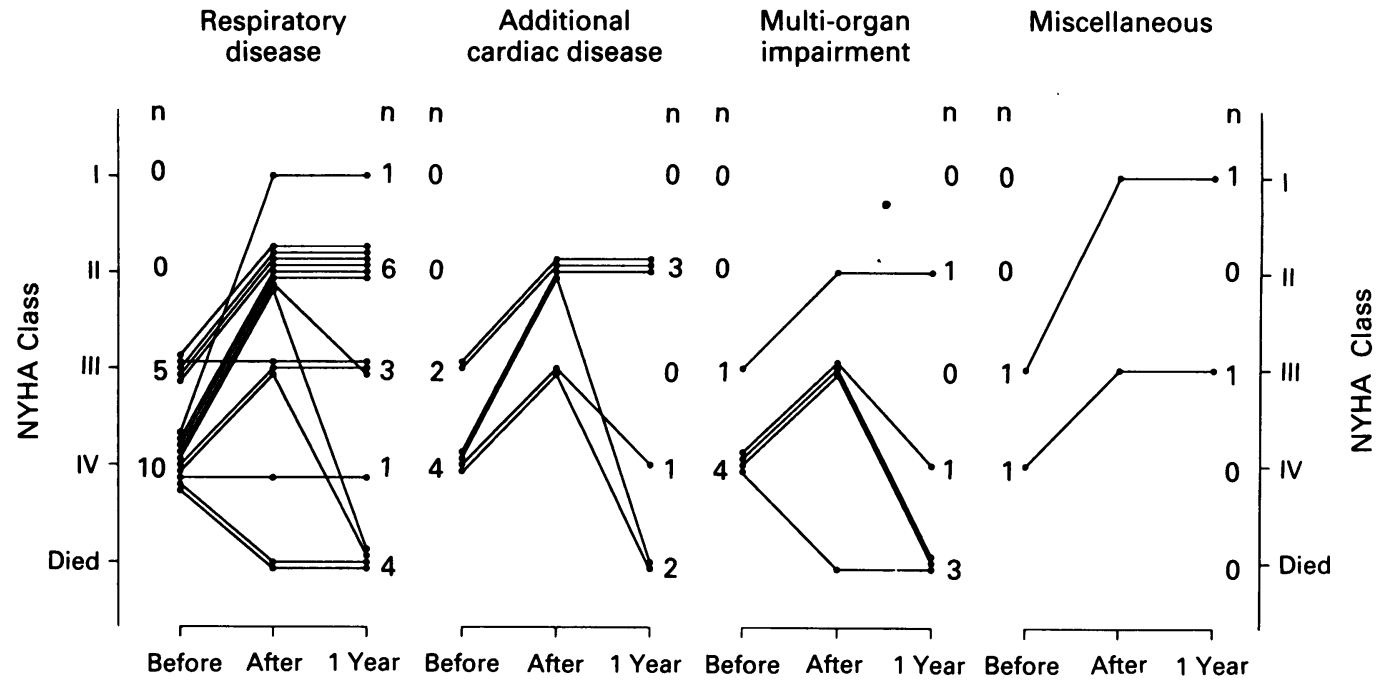

angiography in most patients, was 110 minutes (range 60-225). The mean $x$ ray screening time was 36 minutes (range 10-81). The time from beginning to end of each balloon inflation was 5-10 seconds for the polyethylene/polyvinyl balloons and 3-6 seconds for the Inoue balloon. Aortic pressure before, during, and after dilatation was recorded in 23 patients and fell from a mean of $140 / 71 \mathrm{~mm} \mathrm{Hg}$ to a mean nadir of $52 /$ $39 \mathrm{~mm} \mathrm{Hg}$.

Minor complications occurred in four patients. In one (patient 16) brief syncope developed during balloon dilatation. During balloon dilatation one patient (2) with conduction system disease had a period of asystole that responded to a chest thump: a temporary pacemaker was inserted and the procedure was completed. One patient (case 4) required transfusion for blood loss at catheter changes. One patient (case 20) showed an increase of mitral reflux by one grade: she had no reflux before dilatation and showed mild reflux after. A left to right shunt at the atrial crossing point was detected in three patients but was small $(1 \cdot 2$, $1 \cdot 2$, and $1 \cdot 3: 1$ ) in each.

There were major complications in three patients. A 69 year old woman (patient 1), with both severe obstructive airways disease $\left(\mathrm{FEV}_{1}\right.$ 0.41 ) and considerable orthopnoea required a general anaesthetic in order to lie flat for the procedure: she died of respiratory failure six hours later and in retrospect should have been ventilated for longer. Necropsy showed no cardiac complication. A man aged 69 (patient 23) with breathlessness at rest was severely ill with lupus erythematosus and vasculitis which had persisted despite steroid therapy. He also had chronic obstructive airways disease, left ventricular impairment, and a past history of stroke. He became agitated during the procedure and was given intravenous sedation. This caused increased hypoxia and he required assisted ventilation. Evidence of a hemiplegia became apparent two days after the procedure. He died nine days later. He might have benefited from earlier ventilation. The third patient was a 65 year old woman (patient 14) who had obstructive airways disease $\left(\mathrm{FEV}_{1} 0.67 \mathrm{l}\right)$ with moderately reduced carbon monoxide transfer factor, severe and very diffuse disease of the anterior descending and circumflex coronary arteries, and occlusion of the right coronary artery, considerable pulmonary hypertension, and obesity. The initial arterial oxygen saturation was $83 \%$. Her mitral valve was dilated with the Inoue balloon at 25,28 , and $30 \mathrm{~mm}$ sizes. The left ventricular angiogram after the final dilatation showed that left ventricular function, which had been good, had become impaired by appreciable antero-apical hypokinesia. Left ventricular end diastolic pressure had increased from 15 to $25 \mathrm{~mm} \mathrm{Hg}$ and the ejection fraction had fallen from $71 \%$ to $41 \%$. Review of her angiograms showed that a minor apical change had developed after the earlier dilatations. She died of cardiogenic shock three days later and had evidence of anterior infarction. At the final balloon dilatation the systemic blood pressure had fallen from 130/70 to a minimum of $56 / 48 \mathrm{~mm} \mathrm{Hg}$ during a four second dilatation period. At necropsy diffuse coronary disease was confirmed but there was no evidence of coronary embolism or thrombosis. A change in left ventricular function was also noted in patient 21 who had severe disease of the circumflex and right coronary arteries. Hypokinesia of the inferior surface developed. Left ventricular diastolic pressure rose from 512 to $15-20 \mathrm{~mm} \mathrm{Hg}$ and the ejection fraction fell from $71 \%$ to $36 \%$ but acute left heart failure did not develop.

\section{SYMPTOM OUTCOME}

Figure 2 and table 1 give the symptom classification of the four groups of patients and compare the symptoms before the procedure with those reported at first follow up 1-2 months later. The improvement in symptoms was limited by the associated non-mitral disease or, in some patients, by a suboptimal haemodynamic result due to considerable degenerative changes in the valve. Twenty three patients improved by one or more symptom classes. In those with respiratory disease 11 of 15 patients reported early improvement, two were unchanged, and two had died. All six ted early symptomatic improvement. Four of patients with additional cardiac disease repor- 
the five patients with multi-organ medical problems showed some early symptomatic improvement and one had died.

Two patients have had a repeat balloon dilatation procedure for re-stenosis (one five months and one 21 months after the first.)

Twenty one patients were reviewed one year after balloon dilatation and seven were reviewed at 8-12 months (fig 2 and table 1 ). In the group with respiratory disease two further patients had died: nine $(60 \%)$ continued to show some symptomatic improvement up to one year after dilatation. Of the six patients with additional severe cardiac disease, two patients had died by one year, two showed continued improvement, and one patient had reverted to NYHA symptom class IV. In the group of five patients with severe general medical problems three had died by one year, one again had breathlessness at rest, and one showed sustained improvement.

\section{Discussion}

The patients in this series were all severely disabled by their breathlessness. All had at least one major associated medical problem that put them at an unacceptably high risk as judged by their cardiac surgeon. In these circumstances balloon dilatation of the mitral valve might be considered successful if it produced a small but significant improvement in exercise capacity or prevented clinical deterioration.

In younger patients, most of whom have thin, pliant valves, balloon dilatation has produced excellent results. ${ }^{25-13}$ When the cusps were thickened, immobile, or calcified and there were subvalvar changes in the chordae the haemodynamic improvement was not as good. ${ }^{14}$ Abascal et al found that when patients had mild degenerative changes in the valves $84 \%$ had a "good" result with a final valve area of over $1.5 \mathrm{~cm}^{2}$ whereas in those with considerable changes $42 \%$ had a "good" haemodynamic result and in this group there was a wide scatter of individual results. ${ }^{15}$ In our 28 patients who were unsuitable for cardiac surgery symptomatic improvement was often limited by associated disease or by valve calcification or both. However, $12 \mathrm{had}$ a final mitral valve area $>1.5 \mathrm{~cm}^{2}$ and 21 had a valve area $>1.2 \mathrm{~cm}^{2}$ with 23 reporting improvement by at least one symptom class at early follow up.

Though it resembles diagnostic cardiac catheterisation, percutaneous balloon dilatation of the mitral balloon takes longer, uses larger balloon catheters, and requires much more manipulation of the catheter and guide wire. It also produces severe hypotension for a few seconds while the inflated balloon obstructs the mitral valve. Nevertheless, most of these severely ill patients tolerated the procedure well. There was, however, some risk in undertaking balloon dilatation in patients with severe associated medical problems. Major, fatal complications related to lung ventilation developed in two patients. Those patients with respiratory problems who could be treated with use of only local anaesthetic and no sedation tolerated the procedure well. Patients with respiratory dis- ease who then require sedation or anaesthesia should have close anaesthetic supervision before and after the procedure and after dilatation should be treated in an intensive care unit rather than a coronary care unit.

Severe mitral reflux developed in $2-4 \%$ of patients undergoing balloon dilatation. ${ }^{1016}$ This complication did not develop in our series but it would be a major problem in a patient unable to have emergency mitral valve replacement. This must be considered as a small but significant risk when balloon dilatation is undertaken in patients unacceptable for cardiac surgery. It may therefore be advisable to be cautious with the choice of mitral balloon size. The Inoue balloon, which allows progressively larger dilatations, may help to reduce the incidence of severe mitral reflux. Cerebral embolism and haemopericardium are the two other major but uncommon complications of percutaneous balloon dilatation of the mitral valve.

One patient developed extensive anterior infarction, not due to embolism, after uncomplicated balloon dilatations that had lasted only four seconds. Of our total of 108 patients undergoing balloon dilatation of the mitral valve $22(20 \%)$ had known coronary artery disease and all but one other (patient 21) had tolerated the procedure without overt myocardial impairment. In the light of this complication it seems advisable to restrict the number of inflations and the inflation time in those with critical coronary artery lesions.

The balance of benefit and risk means that balloon dilatation is worth undertaking in patients with severe mitral stenosis who are unsuitable for cardiac surgery. In most patients symptoms will improve. There is some risk attached to the procedure and the improvement in breathlessness may be restricted by the associated disease or because haemodynamic improvement is limited by extensive valve thickening and calcification. Some patients with considerably thickened and calcified valves, however, can obtain good haemodynamic improvement and relief of breathlessness: individual results are unpredictable. For the type of patient included in this series a moderate improvement in symptoms and modest extension of life expectancy can be a sufficient objective to justify attempting balloon dilatation.

1 Inoue K, Owani T, Nakamura T, Kitamura F, Miyamoto N. Clinical application of transvenous mitral commissurotomy by a new balloon catheter. J Thorac Cardiovasc Surg 1984;87:394-402.

2 Lock JE, Khalilullah M, Shrivastava S, Bahl V, Keane JF Percutaneous catheter commissurotomy in rheumatic Percutaneous catheter commissurotomy in rheumatic

3 Hall RJC, Julian DG. Diseases of the cardiac valves. Edinburgh: Churchill Livingstone, 1989:chapter 1 .

4 Palacios I, Block PC, Brandi S, et al. Percutaneous balloon valvotomy for patients with severe mitral stenosis. Cirvalvotomy for patients $w$
culation 1987;75:778-84.

5 Chen $C$, Lo Z, Huang Z, Inoue $K$, Cheng TO. Percutaneous transseptal balloon mitral valvuloplasty: The Chinese experience in 30 patients. Am Heart $J$ 1988;115:937-47.

6 Cohen MV, Gorlin R. Modified orifice equation for the calculation of mitral valve area. Am Heart J 1972;84:839.

7 Grossman $W$. Profiles in valvular heart disease. In: Gross man W, ed. Cardiac catheterisation and angiography. Philadelphia: Lea and Febiger, 1985:359-81. 
8 Sellars RD, Levy MJ, Amplatz K, Lillelei CW. Left retrograde cardioangiography in acquired heart disease. Technique, indications and interpretation in 700 cases. Am J Cardiol 1964;14:437-47.

9 Al Zaibag M, Riberio PA, Al Kasab S, Al Fagih MR. Percutaneous double-balloon mitral valvotomy for rheumatic mitral valve stenosis. Lancet 1986;i:757-61.

10 Vahanian A, Michel PL, Cormier B, et al. Results of percutaneous mitral commissurotomy in 200 patients. $\mathrm{Am}$ J Cardiol 1989;63:847-52.

11 Chen CR, Huang ZD, Lo ZX, Cheng TO. Comparison of single rubber-nylon balloon and double polyethylen balloon valvuloplasty in 94 patients with rheumatic mitra stenosis. Am Heart J 1990;119:102-11.

12 Pektas O, Isik E, Coskun $M$ et al. Late haemodynamic changes in percutaneous mitral valvuloplasty. Am Heart J
1990;119:112-20.

13 Patel J, Vythilingum S, Mitha AS. Balloon dilatation of the mitral valve by a single bifoil $(2 \times 19 \mathrm{~mm})$ or trefoil $(3 \times 15 \mathrm{~mm})$ catheter. Br Heart J 1990;64:342-6.

14 Wilkins GT, Weyman AE, Abascal VM, Block PC, Palacio IF. Pecutaneous balloon dilatation of the mitral valve: an analysis of echocardiographic variables related to outcome and the mechanism of dilatation. Br Heart $J$ 1988;60 299-308.

15 Abascal VM, Wilkins GT, O'Shea JP, et al. Prediction of successful outcome in 130 patients undergoing percutan eous balloon mitral valvotomy. Circulation 1990;82 448-56.

16 Ruiz CE, Allen JW, Lau FYK. Percutaneous double balloon valvotomy for severe mitral stenosis. Am J Cardiol 1990;65:473-7. 